\title{
The influence of genotype on habitat selection of fish and the analysis of population structure
}

\author{
V.S. Artamonova ${ }^{1}$ and A.A. Makhrov ${ }^{2, \star}$ \\ ${ }^{1}$ Faculty of Biology, St. Petersburg State University, 7/9 Universitetskaya nab., 199034 St. Petersburg, Russia \\ 2 A.N. Severtsov Institute of Ecology and Evolution; 33 Leninsky pr., 119071 Moscow, Russia
}

Received July 15, 2015 - Revised November 6, 2015 - Accepted November 6, 2015

\begin{abstract}
We used salmonids, eel and cod to demonstrate the apparent influence of genotype on the migratory behavior of fish and their selection of habitat. These examples indicate that the connection between specific genotypes and certain patterns of migratory behavior is typical of fish. This should always be taken into account in stock structure analysis.
\end{abstract}

Key-words: Genetics / life history / fish / migration / selection

Résumé - L'influence du génotype sur la sélection de l'habitat du poisson et l'analyse de la structure de la population. Nous avons utilisé les salmonidés, l'anguille et la morue pour démontrer l'influence apparente du génotype sur le comportement migratoire des poissons et leur sélection de l'habitat. Ces exemples indiquent que la connexion entre les génotypes spécifiques et certains modèles de comportement migratoire est typique des poissons. Cela devrait toujours être pris en compte dans l'analyse de la structure des stocks.

Mots-clés : Génétique / histoire de la vie / poisson / migration / sélection

\section{Introduction}

There has been an increasing amount of data in recent years indicating the key role of selection in maintaining genetic polymorphism in populations. Studies of human genetic diversity (Nielsen, 2005) suggest that, even in this species, a large proportion of mutations accumulate due to natural selection, despite the ability of humans to transform the environment to their benefit.

It is obvious that genes under selection are unsuitable for the analysis of population structure (Volis and Zhang, 2010). It is only logical that the development of methods for identifying the genes that are subjected to selection is currently the focus of many studies (reviews: Nielsen, 2005; Hoffmann and Willi, 2008).

However, the commonly used methods do not permit identifying all cases of genetic polymorphism that are accounted for by selection. In the case of diadromous fish, this problem is further complicated by the tendency of juvenile carriers of different genotypes to occupy different habitats.

The first theoretical model assuming that carriers of different genotypes adapt better to different habitats within a species range was suggested by Levene (1953). According to that

\footnotetext{
^ Corresponding author: makhrov12@mail.ru
}

study, the possibility of choosing the best habitat must contribute to a balanced frequency of genotypes. This assumption was further developed in recent theoretical studies (review: Hedrick, 2006).

Numerous examples of the influence of genotype (in some cases, even individual gene loci) on migratory behavior, including the preference for specific habitats, are given in the monograph by Golubtsov (1988). This influence can be identified under experimental conditions and in cases where the individuals studied are known to belong to the same population. There are also data demonstrating the association of specific genotypes with specific habitats (environmental association analysis) (Golubtsov, 1988).

However, when a researcher deals with contrasting environments inhabited by two or three groups of specimens rather than with an environmental gradient, it is virtually impossible to assign these groups to one or several populations without the use of tagging.

The purpose of this study is to systematize evidence for the influence of genotype on migratory behavior and environment selection in model (anadromous, catadromous and marine) fish species. We use three examples to demonstrate the necessity of taking into account the migratory behavior of carriers of different genotypes in the analysis of fish stock structure. 
Available data on our model objects allow us to differentiate the phenomena studied from the effect of natural selection in different habitats on different genotypes. Here, by natural selection in different habitats, we mean different death rates of the carriers of a given genotype in different habitats.

Many studies on salmon and eel analyzed here report data on juveniles that were migrating to different habitats but had not reached them yet and, hence, could not have been subjected to habitat-specific selection. Regarding juvenile cod, we deduced evidence from data on tagging individual fish. In addition, we used only the publications where the fish studied were known to belong to a single population.

\section{Atlantic and Pacific salmon (Salmonidae)}

Salmonids are good model species for identifying the influence of genotype on migratory activity. Many species of this family are represented by resident (fish spending all their life in fresh water) and migratory (those performing feeding migrations to the sea) types. Sometimes these two types can occur in one population; in this case, resident males are called dwarf males. Although cases are known where males migrate to the sea after maturation in rivers, sexual maturation of parr typically precludes subsequent smolting (Jonsson and Jonsson, 2011).

In particular, dwarf males maturing in freshwater were found to differ from other individuals of the same population by an increased heterozygosity in protein-coding loci in sockeye salmon (Kirpichnikov et al., 1990), brown trout (Makhrov et al., 1997) and Atlantic salmon (McCarthy et al., 2003). For the latter species, there is also data available on the correlation between dwarfism and the presence of the $* 0 Q$ allele in the regulatory locus $P G M-1 r^{*}$ (Pollard et al., 1994).

Additionally, it was revealed that Atlantic salmon have differences in the mean heterozygosity and frequency of some protein-coding genes between same-age fish that undergo smoltification and those that do not (Crozier, 1998; Pineda et al., 2003). Some alleles of two (of 8 studied) microsatellite loci were found only in fish migrating to the sea at an early age (Pineda et al., 2003). For salmon from the river Itchen (Southern England), it was shown that there are significant, and temporally stable, differences in haplotype frequency of mtDNA between parr and smolts of the same cohort (King et al., 1993).

Data are available on the influence of the fish genotype on the duration of marine migration. In particular, sockeye males performing spawning migration after a year at sea were found to show higher heterozygosity at allozyme loci compared with fish with a longer marine period (Altukhov et al., 2000). A similar dependence was often observed in the Atlantic salmon. Fish migrating to spawn after a winter at sea (grilse) were more heterozygous at the locus coding malic enzyme $(M E P-2 *)$ than fish with a longer marine period. In other studies, two groups compared differed by allele frequency at that locus (references in: Artamonova, 2007). It should be noted, however, that differences in the genetic structure between samples of anadromous fish returning from the sea may be accounted for by the effect of natural selection in different habitats on different genotypes.
In addition, variation of migratory behavior of salmonids is sometimes related to differences in gene expression (review: Larsen et al., 2011).

Nevertheless, salmon provide a whole number of examples showing the influence of genotype on the migratory activity of fish and their selection of environment.

\section{Eels (Anguilla)}

Two representatives of this genus inhabit the Atlantic Ocean and spawn in the Sargasso Sea. Their larvae are spread by currents along the coasts of Europe and North America. By the number of vertebrae and some genetic parameters, they are divided into European and North American eels, which are for that reason regarded as different species (A. anguilla and A. rostrata).

Despite the differences in allele frequencies in some protein-coding genes between eels caught in different rivers on the same continent, a thorough analysis of the entire block of data allowed a conclusion about only one eel population inhabiting the continent. One significant example is the Sdh locus, allele frequencies of which were found to clinally change from north to south. A cline-like distribution of Sdh allele frequency is observed both in recruits and in mature fish, which suggests the presence of certain migration patterns in carriers of different Sdh genotypes (Williams and Koehn, 1984).

Investigations of diversity of microsatellite loci in European eel indicated a weak, but significant, differentiation between fish sampled in different regions (references in Palm et al., 2009; Andrello et al., 2011). However, the studies mentioned did not take into account temporal dynamics of microsatellite frequencies, while the analysis of samples collected in different years at the same geographical point is crucial for the analysis of the population structure of any species. Recent studies of microsatellites in European and American eels, which fulfilled that condition (Palm et al., 2009; Als et al., 2011; Côté et al., 2013), did not reveal any differentiation between regions of the same continent.

Similarly, a weak genetic differentiation between samples of eels collected in different rivers was observed in AFLP and SNP analyses (Gagnaire et al., 2009, 2012). However, the authors of these articles note that the differentiation was probably caused by selection at loci linked to some of the sequences studied.

This implies that eel can be regarded as an example of species for which genetic differences between samples collected in different regions are associated with differences in migratory activity in carriers of different genotypes rather than with the formation of local populations.

\section{Atlantic cod (Gadus morhua)}

Atlantic cod is a typical marine species widely distributed in the North Atlantic and adjacent areas of the Arctic Ocean. The population structure of this species has been the subject matter of discussion for decades. An important aspect of this research is the interpretation of genetic differences between samples of cod collected at different depths. 
Studies of genetic diversity in cod off the Icelandic coast have shown that the frequency of one of the alleles at the pantophysin-coding locus (Pan I) increases with depth (Pampoulie et al., 2006). However, tagging experiments (Pampoulie et al., 2008) suggest that the genotype at that locus in itself has an effect on the time spent by cod at $<200 \mathrm{~m}$ or $>200$ m depth.

Investigations of cod in that area have also demonstrated that the observed and the expected heterozygosity at nine microsatellite loci decrease with depth. This reduction was found to be gradual. Considering that frequencies of pantophysincoding alleles also change gradually with depth, the groupings of cod inhabiting the same coastal area are not viewed as separate populations (Pampoulie et al., 2006).

Thus, the differences in samples, even by two various groups of genetic markers, do not necessarily mean their belonging to different populations. The example with cod shows that such differences are quite likely to be related to the differences in migratory activity of carriers of different genotypes.

\section{Conclusions}

We used salmonids, eel and cod to demonstrate the obvious influence of genotype on the migratory behavior of fish and their selection of habitat. These examples indicate that the connection between specific genotypes and certain patterns of migratory behavior is typical of fish. This should always be taken into account in stock structure analysis.

Despite the absence of mathematical tools in stock structure analysis that would allow for specific features of migratory behavior in fish, some general approaches, which were to a certain extent used in the studies mentioned, can be suggested.

It is obvious that, in cases when direct tagging is impossible for some reason, it is essential to undertake a thorough analysis of materials collected in contrasting environments. Primarily, these ought to be the samples collected near the supposed spatial boundary separating the groupings studied. A discrete or gradual distribution of allele frequencies in the studied genes can be a weighty argument supporting one of the hypotheses (one or two populations, respectively). Besides, a significant inconsistency with the Hardy-Weinberg equilibrium for samples collected near such a boundary would confirm the existence of two independent groupings, while the validity of that equilibrium in all the samples studied would support the single stock hypothesis.

It is also important to note all cases indicating selection at the analyzed loci and to use literature data on other species with an already established connection between specific loci and the patterns of migratory behavior.

In conclusion, it should be highlighted that the groupings of specimens characterized by discrete migratory behavior but belonging to the same population have already been investigated with a special term, "contingents", being used to denote them (Secor, 2005). However, the above examples show that such groupings may be different not only in terms of their migratory behavior, but also by the frequency of their genotypes (which often misleads even geneticists analyzing stock structure).
Acknowledgements. The writing of this article was supported by the Russian Foundation for Basic Research, project 15-29-02550, the Program "The rational use of the Russian biological resources: Basic grounds of management", the Program "Biodiversity of Natural Systems" (subprogram "Gene Pools of Living Nature and their Conservation") and St. Petersburg State University (grant no. 1.50.124.2014 (for V.A.)).

\section{References}

Als T.D., Hansen M.M., Maes G.E., Castongua M., Riemann L., Aarestrup K., Munk P., Sparholt H., Hanel R. and Bernatchez L., 2011. All roads lead to home: panmixia of European eel in the Sargasso Sea. Mol. Ecol., 20, 1333-1346.

Altukhov Yu.P., Salmenkova E.A. and Omelchenko V.T., 2000. Salmonid fishes. Population biology, genetics and management, Blackwell Science, Oxford, 354 p.

Andrello M., Bevacqua D., Maes G.E. and De Leo G.A., 2011. An integrated genetic-demographic model to unravel the origin of genetic structure in European eel (Anguilla anguilla L.). Evol. Appl., 4, 517-533.

Artamonova V.S., 2007. Genetic markers in population studies of Atlantic salmon Salmo salar L.: Karyotype characters and allozymes. Russ. J. Genetics, 43, 221-233.

Côté C.L., Gagnaire P.A., Bourret V., Verreault G., Castonguay M. and Bernatchez L., 2013. Population genetics of the American eel (Anguilla rostrata): Fst $=0$ and North Atlantic oscillation effects on demographic fluctuations of a panmictic species. Mol. Ecol., 22, 1763-1776.

Crozier W.W., 1998. Genetic implications of hatchery rearing in Atlantic salmon: effects of rearing environment on genetic composition. J. Fish Biol., 52, 1014-1025.

Gagnaire P.A., Albert V., Jónsson B. and Bernatchez L., 2009. Natural selection influences AFLP intraspecific genetic variability and introgression patterns in Atlantic eels. Mol. Ecol., 18, 1678-1691.

Gagnaire P.A., Normandeau E., Côté C., Hansen M.M. and Bernatchez L., 2012. The genetic consequences of spatially varying selection in the panmictic American eel (Anguilla rostrata). Genetics, 190, 725-736.

Golubtsov A.S., 1988. Intrapopulation variability in animals and protein polymorphism. Nauka Press, Moscow, 168 p. (in Russian).

Hedrick P.W., 2006. Genetic polymorphism in heterogeneous environments: The age of genomics. Annu. Rev. Ecol., Evol., and Systematics, 37, 67-93.

Hoffmann A.A. and Willi Y., 2008. Detecting genetic responses to environmental change. Nat. Rev. Genetics, 9, 421-432.

Jonsson B. and Jonsson N., 2011. Ecology of Atlantic Salmon and Brown Trout. Habitat as a Template for Life Histories. Springer, Dordrecht, 708 p.

King D.P.F., Hovey S.L., Thompson D. and Scott A., 1993. Mitochondrial DNA variation in Atlantic salmon, Salmo salar L., populations. J. Fish Biol., 42, 25-33.

Kirpichnikov V.S., Muske G.A., Scholl-Engberts A.D., Chernov V.M. and Borchsenius S.N., 1990. Genetic structure and allele frequency dynamics in the sockeye salmon population of Lake Dalneye, Kamchatka. Aquaculture, 84, 13-25.

Larsen P.F., Schulte P.M. and Nielsen E.E., 2011. Gene expression analysis for the identification of selection and local adaptation in fishes. J. Fish Biol., 78, 1-22.

Levene H., 1953. Genetic equilibrium when more than one ecological niche is available. American Naturalist, 87, 331-333. 
Makhrov A.A., Kuzishchin K.V. and Altukhov Yu.P., 1997. Association of allozyme heterozygosity with growth rate and ecological differentiation in brown trout Salmo trutta L. Russ. J. Genetics, 33, 568-573.

McCarthy I.D., Sanchez J.A. and Blanco G., 2003. Allozyme heterozygosity, date of first feeding and life history strategy in Atlantic salmon. J. Fish Biol., 62, 341-357.

Nielsen R., 2005, Molecular signatures of natural selection. Annиal Review of Genetics, 39, 197-218.

Palm S., Dannewitz J., Prestegaard T. and Wickströmet H., 2009. Panmixia in European eel revisited: no genetic difference between maturing adults from southern and northern Europe. Heredity, 103, 82-89.

Pampoulie C., Ruzzante D.E., Chosson V., Jörundsdóttir L., Taylor V., Thorsteinsson V., Daníelsdóttir A.K. and Marteinsdóttir G., 2006. The genetic structure of Atlantic cod (Gadus morhua) around Iceland: insight from microsatellites, the Pan I locus, and tagging experiments. Can. J. Fish. Aquat. Sci., 63, 2660-2674.

Pampoulie C., Jakobsdóttir K.B., Marteinsdóttir G. and Thorsteinsson V., 2008. Are vertical behaviour patterns related to the pantophysin locus in the Atlantic cod (Gadus morhua L.)? Behaviour Genetics, 38, 76-81.

Pineda H., Borrell Y.J., McCarthy I., Vázquez E., Sánchez J.A. and Blanco G., 2003. Timing of first feeding and life history strategies in salmon: genetic data. Hereditas, 139, 41-48.

Pollard S.M., Danzmann R.G. and Claytor R.R., 1994. Association between the regulatory locus $P G M-1 r^{*}$ and life-history types of juvenile Atlantic salmon (Salmo salar). Can. J. Fish. Aquat. Sci., 51, 1322-1329.

Secor D.H., 2005. Fish migration and the unit stock: three formative debates. In: Cadrin S.X., Friedland K.D., Waldman J.R. (eds), Stock identification methods. Application in fishery science, Elsevier Academic Press, Amsterdam etc., 17-44.

Volis S. and Zhang Y.-H., 2010. Separating effects of gene flow and natural selection along an environmental gradient. Evol. Biol., 37, 187-199.

Williams G.C. and Koehn R.K., 1984. Population genetics of North Atlantic catadromous eels (Anguilla). In: Terner B.J. (ed.), Evolutionary Genetics of Fishes, Plenum Press, New York and London, 529-560.

Cite this article as: V.S. Artamonova and A.A. Makhrov, 2016. The influence of genotype on habitat selection of fish and the analysis of population structure. Knowl. Manag. Aquat. Ecosyst., 417, 3. 